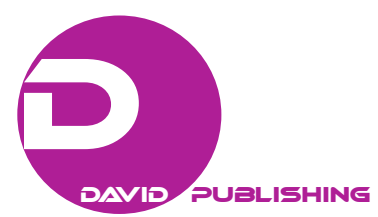

\title{
The Portuguese Newspapers Market Between Consolidation and Concentration Strategies
}

\author{
Paulo FAUSTINO \\ Center of Investigation of Journalism and Porto University, Portugal
}

\begin{abstract}
The main objective of this research is to assess the existence (or lack) of media concentration in the Portuguese dailies newspaper sector, and to evaluate the extension to which this situation may be compromising fundamental society values: freedom of speech and right of access to information. Authors resorted to market indicators, namely total average circulation, number of copies per issue, business volume and advertising investments. These indicators are found to be complementary: some indicators evaluate group position in the readers' market, whereas other evaluates group position in the general market and the advertising market in particular. Based in this market information, we used quantitative models (HII, CR4 and Noan) to measure de concentration in the newspaper segment. Additionally we tried to demonstrate that to analyze the dailies newspaper concentration situation in Portugal a holist perspective of the media market is needed, using a country context to understand some local characteristics and market structure and political, economic, social and technological dynamics. Additionally, there are evidences that existing concentration indexes are not conclusive because of potential replacement effects in the Portuguese media sector.
\end{abstract}

Keywords: press, market, concentration, consolidation, pluralism, multimedia, technologies, change, advertising, readers, circulation

\section{Introduction}

Free and equal media access for all citizens is a modern society ideal. In a fully competitive market, no information access limits would exist and no media company would have sufficient power to display different and independent behavior from other players and consumers. Nevertheless, reality is different and media markets follow a seemingly irreversible trend towards concentration. This media concentration trend was long ago foreseen by some researchers. Toussaint (1979), for example, when referring to the case of the written press, considered that companies would increasingly tend towards concentration, for two fundamental reasons: (1) to achieve high return on investment through mass sales (making it possible for advertisers to invest in publications with less issues); (2) to develop products, orientated to specific audiences, capable of attracting more advertising investments.

The business concentration phenomenon is a relatively old study area. Marx (1968) made references to property concentration. Concerns about concentration have been progressively increasing, especially due to initiatives undertaken by national governments and international institutions. In the particular case of the media

Paulo FAUSTINO, Ph.D., Professor of Media Policies, Economics, Management \& Marketing, Porto University and Polytechnic Institute of Leiria; President of Media XXI - Consulting, Research \& Publishing and Presidente of International Media Management Association (IMMAA). 
sector, these concerns have been evident in some studies conducted by the European Commission. Increasing concerns relatively to the media sector are justified by its enormous importance and its cultural and social impact on society. Despite the importance of this issue, concentration studies have, nevertheless, not always been conclusive in the sense they have proved unable to provide sufficient information to lead to adoption of efficient measures to avoid situations of abuse of dominant positions. It is partly possible to understand that studies may sometimes be inconclusive regarding the negative effects of concentration. It is a complex and fairly subjective matter to state that a dominant position within a particular market may be compromising freedom of speech and opinion diversity.

The issue of business concentration has been widely discussed and studied within the scope of industrial and political economy, since it may have important political, economic and social consequences. As previously mentioned, media concentration research has been increasing in the European Union, where great concerns exist relatively to national and international audiovisual media concentration. In February of 1990, the European Parliament approved a resolution related to media concentration that constituted the starting point for further analysis aimed at the development of a Green Book by the European Commission. The press sector, especially the important segment represented by daily newspapers, has rarely been cause for concern in recent years. In general terms, media concentration issues have been followed by the European Council since 1967. The first European Council report on media concentration was published in 1972. Following this, many studies were performed in order to evaluate the new market situation. The main objectives of the first concentration studies on the press sector were:

- Quantitative descriptions of market influence within relevant markets, taking their specific functional characteristics into account;

- Analysis of development factors for press concentration, including market penetration aspects, market share measurements, etc.;

- Property and market concentration analysis, in terms of industrial influence;

- Assessment of the effect of anti-concentration measures, including use of legal and financial criteria.

Effectively, we have been witnessing, in many cases, a trend towards vertical concentration, where the process is controlled from the beginning to the end of the production chain, and towards horizontal concentration, aimed at controlling a maximum amount of similar products. These two kinds of concentration tend to be combined, originating large groups, sometimes multinational, controlling not only newspapers, but also radio and television stations, information, advertising, and distribution agencies, as well as non-core activities such as book, record and video publishing, etc. In all cases, an effort is made to attain greater dimension through costs and risk rationalization, with the purpose of wielding more power, either through innovation or sector control.

Positions assumed relatively to concentration usually point to two hypotheses, both of which assume a business concentration scenario. The first and more optimistic approach sustains that concentration is a natural process within a free market economy, where mergers and partnerships are efficient growth strategies, in the sense they allow operational cost reductions whilst simultaneously allowing an improved product offer to the public and an increase in the diversity of media supports made available to consumers. The second approach, however, looks at concentration phenomena as a danger to democracy and freedom of information, since, when held by a limited number of businessmen, media may start to limit information, with contents starting to follow 
economic and profit vectors, in an unbridled fight for audiences and advertising investments.

The discussion held in Portugal is not new and assumes the same contours of previous and still ongoing debates all over the world. Concurrently with this polarised debate, centred on "commerce-media" or "culture-media" (Bogart, 2000; van Cuilemburg, 2003), a third, more conciliatory approach appears, which suggests that media sector businesses may grow according to a free market economy dynamics, provided they respect certain rules aimed at safeguarding public interest. Nevertheless, the central question one may ask is the following: How to define these rules and how to define public interest?

In this research, the authors focus on newspapers segment, for which the author collects accounting data and official statistics and yearbooks (e.g., APCT and Marktest) in order to obtain three distinct concentration indicators, namely (1) the CR4 (Concentration Ratio of the four largest companies), (2) the HHI (Herfindhal-Hirschman index), and (3) the Noam Index. There has been a huge amount of debate about media concentration in Portugal within the last years. However, few concrete data have been analyzed for a more enlightening scenario of the real situation to be achieved, as well as for the debate to be enriched and ways that ought to be followed by Portuguese institutions about these matters to arise. Before all, it is necessary to promote a serious discussion based on concrete information and situations. The first points that should be discussed, and probably the most important, are:

- Is there actually a media business concentration in Portugal?

- Which types of concentration and companies may be identified?

- What are the advantages and disadvantages to the citizens?

As may be deducted, several questions, some of which are sometimes treated in a superficial way, still require answers. What is effectively at stake is to establish whether citizens have benefited or been harmed by these business practices. Due to the aforementioned reason, analysis of this issue should, in a complementary fashion to the discussion and academic interest elicited, be carried out from a more practical and objective perspective, given its actual impact on the market and on information provided to consumers (citizens). In the present part of this research, we attempt to analyze the current situation of press concentration in Portugal; one of the segments that caused significant concern within the press sector was that corresponding to general information publications, mostly daily press.

\section{Objective, Research Question and Methodology}

The main objectives of this research are: (1) to describe the daily newspaper concentration situation, (2) to identify appropriated indicators to measure press concentration; and (3) to analyze the critical factors of concentration and media pluralism. According to Kopper (in Gustafsson, 1995, pp. 98-100), the various methodologies used in concentration studies have not always been successful, since they consist of mere statistics or diagrams. Knowledge of cause-effect relationships regarding concentration is excluded. According to this author, although we still lack some essential knowledge of concentration processes (see Table 1), the following fundamental issues need to be considered in concentration analysis:

(1) What are the fundamental elements in establishing newspaper market shares, in terms of market process dynamics?

(2) What kind of role is played by the complex and practical mix resulting from cooperation and competition between newspapers from an individual country or region, and what will be the resulting product quality, in terms of concentration effects? 
(3) What has been the effect, in relation to press concentration, of other media aimed at the same audiences and using the same kind of financial resources (for example, local advertising)?

Table 1

Concentration Analysis Methods and Difficulties

\begin{tabular}{|l|l|}
\hline General Methods & Difficulties \\
\hline Relevant markets; specific functional characteristics & Global market structure \\
\hline Market penetration; Audience shares & Competitive structure \\
\hline Ownership and influence; legal and financial criteria & Industry dynamics \\
\hline
\end{tabular}

Note. Source: Gustafsson, 1995.

Still according to Kopper (in Gustafsson, 1995, p. 101), some difficulties need to be taken into account in concentration studies, whereby the following perspectives need to be considered: (1) A general knowledge of the global structure of the market; (2) A global understanding of the competition structure; and (3) A coherent structure, in order to be able to understand press industry dynamics. Although the purpose of this research is not in-depth analysis of the multimedia concentration process, it is our intention, as may be confirmed further on, to analyze concentration within the press sector by considering both qualitative and quantitative approaches, although the quantitative approach will prevail. According to Faustino (2003), analyses conducted on media concentration in Portugal lack some factual accuracy concerning other approaches that is being necessary to explore, namely:

- Relationship between media evolution and pluralism;

- Differentiation between single and multimedia concentration;

- Concentration context in Portugal, within the scope of market dynamics;

- Comparison of the Portuguese reality with other country realities, especially regarding countries of similar dimensions;

- Identification and quantification of some variables capable of expressing the existing level of concentration, in a more objective fashion.

According to Talon (2000), concentration studies should make a conceptual distinction between static and dynamic concentration. Static concentration relates to concentration as a technical phenomenon, where distribution of production means by an increasingly smaller number of businessmen is evaluated. The dynamic perspective considers concentration as a form of company growth through external procedures: merger, incorporation, etc. On this level, concentration confers important advantages to the company, since it allows greater benefits, an increase in production diversification and a better competitive position within the market. It may even turn into a way of eliminating competitors, allowing the company to achieve a dominant position, by limiting or restricting competition.

Establishing a hypothesis is not about making mere suppositions without proposing specific conjunctures and defining them in an adequate manner, I order for analyzed data not to represent simple redundancy or mechanical recurrences. We need to be able to derive reflections and ideas from hypotheses that will enable us to focus on the research issue, orientate the research process and develop concrete conclusions (Iglesias, 2005). One of the core aspects of the methodology used in this paper is determining concentration levels. In this sense, it was necessary to define concrete indicators allowing us to evaluate the level of business concentration, for the various approaches we made to the subject in question. From our analysis of presumptions lacking a sustaining 
basis, we would like to emphasize the following ideas:

(1) Sector technological developments are usually not considered, despite the fact they allow an increase in the media, as well as enabling the appearance of new products, replacement or complementary, such as online newspapers.

(2) The Portuguese press market characteristics and specificities are usually not considered, namely: i) tradition of national and regional weekly publications; ii) reduced market dimension, leaving no room for more media operators and; iii) low prevalence of daily newspaper reading habits, which does not lead to a great daily press dynamics.

(3) Low penetration of "national" newspapers outside the large urban centers of Lisbon and Porto is usually not taken into account. Average circulation statistics and audience studies allow us to emphasize the importance of regional and local press in meeting consumer information needs.

(4) A dynamic approach to the media market has not been considered. An analysis based only on the current situation is limiting and does not take short and medium term developments into account. More than a situational analysis, a prospective analysis of the media is needed, based of five key elements: multimedia activity, ITC impact, audiovisual strength, information/entertainment, and local and regional information.

(5) Finally, concentration studies relative to information markets lack contents analysis ${ }^{1}$, which would allow us to identify similarities and differences between several media products, both within different segments and within the same segment: Do these meet the same kinds of information needs?

Within an academic context, the concentration subject has traditionally been included within the scope of industrial economy. Nevertheless, the field of economics and management applied to the media sector has progressively demarcated its own grounds within the last few years, having gained some autonomy within this research area. Regarding the specific methodology used in developing this part of the paper, and as a complement to a review of reference authors within the field of media economics and politics (mostly foreign, since very little literature is available on this subject in Portugal), the author resorted to various information sources, namely:

- Annual reports and other documents published by media companies, sector associations and advertising companies;

- Documents and guidelines divulged by some national, international and EU institutions;

- Magazine and newspaper articles related to the media sector.

Therefore, some legislation on concentration was analyzed, mostly from the Portugal, but also from the EU, with the purpose of establishing a legal and judicial framework. We also had access to annual reports (operational results) issued by main media groups. Given their importance and frequent use by operators, we also resorted to studies and market information, namely regarding audience data, advertising investments and circulation. As mentioned, to assess the level of concentration in an industry for a given year, we use two indices that can be calculated using the same underlying numbers: the $\mathrm{C} 4$ ratio and the "Herfindahl-Hirschman Index" (HHI). A third index, referred to as a Noam index, divides the HHI by the square root of the number of voices, for a Media Ownership and Concentration Index. The first one (CR4) focus on the weight of the dominant players, aggregating the market share percentage of the largest four companies in an industry. This index (C4 ratio) aggregates the market share percentage of the largest four companies in an industry. If the

\footnotetext{
${ }^{1}$ Ribeiro (2007) presents an analysis of pay TV carriers contents in the context of the highly concentrated Portuguese pay TV industry, concluding that no meaningful differences could be found between the services offered by alternative operators.
} 
market shares of the top 4 firms were, for example, $40 \%, 30 \%, 10 \%, 10 \%$, with 5 other firms holding $2 \%$ each, the $\mathrm{C} 4$ index would be 90 . The formula for the $\mathrm{C} 4$ ratio is:

$$
C 4_{j}=\sum_{i}^{4} s_{i j}
$$

where $S_{i}=$ firm's $i$ market share of a given industry $j$ and where firms are ordered by size of market share.

Regarding the HHI is equal to the sum of the squares of the market shares of all market participants. Please note that this index only includes known market shares, so the category others (see below) is excluded from the calculation. The HHI can range between zero - where the share of each firm is infinitely small - and 10,000 , when a single firm accounts for $100 \%$ of the market. In the example above, the HHI would be HHI = $40^{2}+30^{2}+2 \times\left(10^{2}\right)+5 \times\left(2^{2}\right)=2,720$. The formula for this index is:

$$
H H I=\sum_{i=1}^{f} S_{i}^{2}
$$

where:

$f=$ number of firms participating in an industry;

$S_{i}=$ each firm's market share;

$i=$ firm in a given industry.

The US Department of Justice's antitrust enforcement guidelines classify market concentration levels as follows:

$\begin{array}{ll}\mathrm{HHI}<1,000 & \text { Unconcentrated Market } \\ 1,000<\mathrm{HHI}<1,800 & \text { Moderately Concentrated Market } \\ 1,800<\mathrm{HHI} & \text { Highly Concentrated Market }\end{array}$

Finally, the third concentration index (the Media Ownership and Diversity Concentration Index (the Noam-index)) has been specifically developed for the case of media industries, normalizing the HHI in order to take into account the number of available voices. To be more precise the Noam index corresponds to the ratio of HHI index and the square root of the number of voices in the market. In this note, the three concentration indexes will be used (both individually and jointly) to provide objective measures of dailies newspaper market) and, in that sense, contribute to enlighten the debate on the issue of concentration in Portuguese media markets. The Noam Index takes into account the number of voices available. Market power alone does not reflect media diversity. The availability of alternatives, even if they are small, permits different viewpoints. A media market consisting of four major and four minor firms is more diverse than one of merely four major firms, even if the market power indices would be virtually identical. This can be defined by the equation:

$$
M O C D I=\frac{H H I}{V}=\frac{\sum_{i}^{n} s_{i}^{2}}{\sqrt{n}}
$$

where:

$n=$ number of firms participating in an industry;

$S_{i}=$ each firm's market share;

$i=$ firm in a given industry.

Using our numeric example, this index would result in: 


$$
M O C D I=\frac{H H I}{V}=\frac{2,720}{\sqrt{9}}=\sim 907
$$

The important thing to remember is that market definitions and indices are never perfect, and most useful if applied consistently over time and across countries. If the thermometer drops it is getting colder, whether the scale is Celsius, Fahrenheit, or Reaumur. In synthesis, to develop this research on press concentration and apply the models described above, we assume the following research questions (RQ) about the Portuguese market:

RQ.1 - How can we describe the daily newspaper concentration situation?

RQ.2 - Can we identify some specific characteristics of newspaper market?

RQ.3 - What are the appropriated indicators to measure press concentration?

RQ.4 - Does concentration result from a consolidation strategy in media?

RQ.5 - What are critical factors to study the concentration and media pluralism?

\section{Literature Review}

As suggest Kopper (in Gustafsson, 1995, pp. 102-103), the results of concentration studies that follow a traditional line of thought seldom produce indicators of future development. The results of those studies are almost always solely quantitative.

One of the main needs of press concentration studies is to consider structural analysis of market strengths; that is to say, to better consider dynamic inclusion factors and quantitative studies. Kopper (in Gustafsson, 1995, pp. 100-1002), recommends a "Market Integrated Analysis" (MIA). On a press concentration level, this approach entails the following considerations and questions: Defined media markets, Competitive Layers, Comparison between players, Market and Competition Types and Integration of other media. Consequently, we are still lacking recent global comparative studies on the press sector, in terms of competition, markets, concentration and economic and social dynamics, both on an international level and within a local context (Portugal) in particular. One of the main factors contributing to this situation is the lack of national comparative statistical data. Also, no homogeneous European database exists for this kind of information: national data are not directly comparable. As an anticipated recommendation, we would like to affirm that one of the main challenges media researchers will face within the next few years will be attempting to convince European institutions to develop a single project aimed at defining press markets within European countries.

Some of the difficulties in discussing media concentration — especially concerning its current and potential effects - have been inaccurately used, which has originated some confusion in the discussion of this issue. Therefore, and according to Picard (1988), it is important to distinguish between two concentration-related concepts: property concentration and strictly economic concentration. Property concentration is assessed by considering the number of media units (or products) or the percentage of property held by dominant companies in a particular region or country, or on an international level. For the second concentration concept—regarded in a strictly economic sense - a particular geographical market is clearly defined and the market share held by any company or group within that market is considered. There is a relationship between both concepts, although they are not synonyms. The first concept is used in property trend analysis and to understand the extent to which company operations may potentially influence discourse and public opinion. The second concept is important in the application of anti-trust legislation, based on economic measures, in order to fight negative effects of monopolies. Many specialists explicitly quote economic benefits as the fundamental reason 
behind acquisition operations and business concentration movements. However, they usually ignore the existence of internal pressures.

According to Picard (1988), many acquisitions take place not only to obtain financial profits, but also for other reasons, such as: (1) to obtain duty and tax advantages; (2) to generate large scale economies; (3) to reduce risks and control essential resources; and (4) to reduce revenue oscillations and secure financial stability. Following this line of thought, Tabernero (1993) considers that growth strategies of media companies and industry concentration processes may lead to the following advantages:

- Power and prestige for company owners and managers;

- Synergies between each company's different media supports;

- Dominant position within the market;

- Sharing of knowledge between companies;

- Risk diversification;

- Greater innovation possibilities;

- Career opportunities for employees.

As stated by Nieto et al. (1989, pp. 43-44), it is possible for daily newspapers and magazines to keep various ideological orientations or have different specialized contents. Nevertheless, market structures for each publication may obey a previously defined structure. Diversity in ideological informative contents does not necessarily imply a market presence representing a response to a plural configuration. That is, different media concentration processes may originate situations where abuse of information power is detected. However, not all concentration processes necessarily lead to a reduction in information diversity. According to Cavallin (in Gustafsson, 1995), media concentration analysis should take four initial issues into account:

- Vertical versus Horizontal concentration: Is it possible for a company to control various media stages, i.e., production, distribution, advertising, etc., or can it simply aspire to control an increasing number of similar products (newspapers, television channels, etc.)?

- The concept of control, as a result of generalization of the notions of property agreements, property and alliances: Are corporate strategies used with the objective of gaining control over other company assets, or with the more specific purpose of establishing monopolies or oligopolies?

- Multimedia versus single media concentration: Does concentration involve several kinds of information support, or just one?

- Dynamic and static concentration notions: Are we involved in an attempt to eliminate low-level competition within the media sector, or are we trying to stop a process where some aspects appear threatening? Or do we defend both notions depending on the country involved and its degree of media concentration?

European radio and television traditions, whether these are a public service or a state dominated sector, differ considerably from press sector regulations, the latter sector traditionally consisting of a set of private companies operating within a free competition market, as happens in Portugal. The press, especially dally press, has been a classic topic in media concentration debates since the 19th century. However, current press concentration concerns are not as prevalent as they used to be in the past, given the importance and impact of audiovisual media in society. Consequently, and as suggested by Picard (2002) in more recent years, concentration and the growth of media conglomerates have originated interesting discussion topics not only in schools, but also in public debate. What is surprising is not what has been happening, but the fact that not many people have noticed the changes occurred within the media sector. 
Recent events are not new, nor do they represent a rapid transformation associated to the end of the 20th century. If we - citizens - want to respond to these developments we will need, meanwhile, to attempt a better understanding of the nature of these problems. Within this scope, Compaine (2005, p. 98) states that "media companies have indeed grown over the past 15 years, but this growth should be understood in context. Developed economies have grown; therefore, expanding enterprises are often simply static, in relative terms, or their growth appears less weighty". According to Jones (2005), this phenomenon is common to Portugal and Spain and may be explained by saying that Latin countries skipped the "press era", having directly entered the audiovisual era. This would explain the lack of reading habits among the population: There are still many families where the first literate generation is the youngest. Given this, free newspapers may assume an important function, since they are usually read by nontraditional press readers, who may not be willing to pay for an informative daily newspaper. ${ }^{2}$

Considering the current trend towards the presence of companies from other economic activity sectors within the media universe (for example, telecommunications, banks, construction, distribution, industry, etc.), analysis of a given company or group influence must not ignore its ability to influence other businesses, nor synergies that may be developed at different levels, credit facilities, complementary distribution/promotion channels used and infrastructure and management team sharing, amongst other factors. It is in this context that several authors stand out, such as Tabernero (1993), Albarran (2005), and Picard (2002), amongst various others, having delved into the concentration issue and understands some market dynamics and economics objectives from media companies. Other media researchers, such as Mosco (1996), Garham (1990), and McChesney (2000), have chosen to include concentration studies in the scope of media political economy but with critical approach about the commercial media company's market orientation.

According to Picard (1988),

A more sophisticated concentration measure, the Herfindahl Index, is especially useful when measuring the degree of concentration in a situation where multiple competitors exist. This index takes into account not only the percentage of the total industry owned by large companies, but also the total number of companies existing in the market, as well as the percentages owned by each individual company. This index expresses concentration according to a scale varying between $1 / \mathrm{n}$, when all competitors have equal dimensions, to 1,000 , when a sole company controls the entire market. (p. 63)

Effectively, the Herfindahl-Hirschman Index (HHI) is one of the most widely used methods to measure concentration $^{3}$. It is simple, since it allows calculation of concentration levels using the square of the sum of company market shares within a specific sector. However, according to Noam (2009, p. 412): "The question is whether this traditional measure of concentration is appropriate for media. Adopting the HHI or any other measure does not by itself imply adopting a particular threshold definition as to what constitutes concentrated market for medium".

Nevertheless, in order to use this method it is essential to have official and trustworthy market information, which is not at easy goal to achieve in Portugal, since there is a generalized lack of official comparative information and the definitions of homogeneity of editorial contents within a specific segment and the relevant market that should be considered present difficult tasks. Consequently, concentration measurements should not

\footnotetext{
${ }^{2}$ Based on statements made during the XXI International Summer Course in Cascais, in 2005.

3 Although recognising the importance of indicators such as HHI, some authors (e.g., Eli Noam) consider that it is necessary to create a new indicator adapted to the media market that could be more conclusive about the pluralism status, namely by analysing the number of voices - media options - available in that market.
} 
be limited to the choice of a good index. Three main problems exist regarding all concentration measurements:

- Existence of company holdings;

- Choice of the concentration object, which essentially corresponds to the problem of market definition;

- The static character of measurements, these being unable to provide timely information on market share evolution for the individual companies involved.

The term concentration refers to the degree of existing monopoly within a given business activity or sector, which is the extent to which a series of different sector activities are controlled by the same entity. According to this definition, the concept of concentration may be translated into constitution and existence of large dimension economic groups that, through adoption of a multimedia strategy, lead and dominate different media activities, including the traditional media: press, radio and television. In other words, the concept of concentration may be related to the concept of property. It becomes possible to talk about property control, since the sector becomes dominated by a small set of companies and editing groups. According to this approach, concentration may be characterised by two distinct aspects:

(1) A trend towards the merger of editing companies, usually referred to as industrial concentration;

(2) A trend towards editing concentration, which means that a sole editing team is able to prepare written press products related to the same topic but adapted to publications aimed at different target groups.

From the eighties and nineties onwards, private media companies have managed to reach a moderate level of multimedia diversification, operating within several media sectors. The very first diversification processes were conducted by newspaper and magazine publishers, which simultaneously started publishing books and free materials. Multimedia diversification processes increased steeply from the eighties onwards, which implies, in a strict sense, that companies started to own press and audiovisual media: technological innovations and audiovisual industry liberalization allowed groups with greater resources to acquire radio and television channels, cable and satellite infrastructures, Internet servers and other information and entertainment supports. According to Picard (2002), economic concentration has rapidly increased within electronic distribution industries (television channels, radio stations and cable network systems). When contents are considered, however, concentration levels have decreased, at least in some particular segments. It is possible to refer book-editing, magazines aimed at mass consumption, film production and cable networks as examples of segments where this decrease was observed.

The reasons for developing multimedia strategies and behind acquisitions and mergers are mostly of a financial character. According to Tabernero (1993, p. 25) “... new product launch corresponds to a "natural growth' strategy: companies make use of their knowledge of a particular market or type of media business". In the first case, companies diversify their activity without widening their geographical operation area; in the second case, companies expand their business into a new market. Both approaches may appear together, when a company starts a business where it has management experience within a market in which it already has other media interests. Multimedia diversification usually results in three different kinds of advantages for media groups: (1) It allows diversification of business risks; (2) It allows the company to enter new areas with growth potential; and (3) It allows companies to create synergies.

Despite these advantages, most companies that followed a multimedia diversification strategy encountered more problems than they expected. Sometimes, companies are unable to comply with the established deadlines for integrating new acquisitions, thereby becoming unable to obtain a satisfactory return on investment. Media acquisition costs constitute one of the main causes for diversification strategy failure. The advantages of 
acquiring different kinds of communication supports not always justify the fact that some media companies acquire others for prices much higher than values calculated from an analysis of their corresponding accounts. Some analysts display more caution regarding the ability to create synergies from multimedia diversification.

Some empirical studies seem to indicate some productive, commercial and financial synergies between different media. However, these synergies are not advantageous to the extent where they are able to override management errors in situations where companies are acquired at excessively high prices. On this topic, Albarran (2004, p. 90) considers that "mergers may not work because companies sabotage agreements by repeatedly making the same mistakes, namely:

- Paying too much and offering huge rewards, leaving most of the economic gains resulting from the merger to target company shareholders;

- Exaggerated estimations regarding cost savings and synergies, leading to poor performance and shareholder disappointment;

- Lack of knowledge regarding integration operations following the merger, which leads to customer and employee frustration and delays in the achievement of potential benefits;

- Obsession with cost reductions, which may result in poor business performance, if low rewards, unable to maintain salary levels and top quality employees, are offered".

Therefore, media concentration studies must nowadays be increasingly conducted from a multimedia perspective (as well as taking the diversification strategies adopted by media companies into account), since the influence exerted by the press in public opinion tends to decrease (on the account of its dilution given the large offer of electronic media) and considering that what is fundamentally at stake is a group's general ability to influence public opinion through several media supports. Also, almost no groups exist nowadays whose activity is restricted to a single kind of media. Companies are currently developing their activities from a multimedia perspective instead of a single media approach. And according to Noam (2009, p. 440): "The fundamental problems of newspapers are the basic economics of the information business...high fixed costs, low marginal costs, and commoditization (for non-local content and advertising). Online news sites accelerate the trends. In this, newspapers are note alone but in good company as part of a fundamental trend in the information sector.

\section{Portuguese Newspapers Market Case Analysis}

This section investigates the degree and the evolution of concentration in the Portuguese newspaper market, which, for the purposes of this study corresponds to the market of Portuguese newspapers with national coverage, including: National daily general information newspapers; National daily sport newspapers; and National daily economy newspapers. At the light of this market definition, the list of the firms participating in the Portuguese market and their respective daily average circulation is provided in the following Table 2 (in Appendix).

To evaluate the degree and the evolution of concentration in the market of Portuguese national daily newspapers, the author has considered three distinct variables: Circulation, Audiences, and Advertising revenues. First, it is worth noting that these variables provide valuable information on the concentration trends in both advertising and circulation markets. Indeed, due to the two-sided nature of newspaper markets (with newspapers constituting platforms between readers and advertisers), concentration phenomena in newspaper industries might impact both advertising and circulation markets. Accordingly, to assess the phenomenon of concentration in all its extension, indicators from both markets must be considered. Second, it is worth noting 
that the assessment of concentration in the circulation market was based on two distinct indicators: circulation and audiences, which, in the case of print press, do not necessarily coincide as one newspaper is usually read by more than one person. In what follows, the author investigates concentration trends for each of these variables starting with the average circulation, followed by audiences and advertising revenues.

\section{Circulation}

The empirical evidence on the average circulation of Portuguese daily national newspapers' circulation from 1995 till 2013 (vide Table 2) reveals two interesting trends: on the one hand, the average circulation of paid newspapers (e.g., Diário de Notícias or Jornal de Notícias) has stagnated or even declined. On the other hand, the total circulation (including both paid and free newspapers) has increased significantly until 2007, illustrating the remarkably positive performance of free newspapers. However, it should be noticed that since then the performance of free newspapers was less brilliant, with free newspapers facing a small reduction on average circulation following the crisis in advertising markets and the subsequent reduction of free newspapers' revenues. This contributes to the gradual decline in overall circulation values of national newspapers, from 2007 to the most recent year analyzed: 2013. Rearranging the data on average circulation (see Table 2 in Appendix), Table 3 (in Appendix) aggregates the market shares of newspapers under the control of the same media group, stressing the relative importance of each media group participating in the Portuguese newspaper market.

The evidence on Table 3 (in Appendix) suggests that the Portuguese market of daily national newspapers is highly concentrated, with the joint market share of the two major media groups in the dailies newspaper industry (Cofina and Controlinveste) reaching very high values. Despite this context, it should be noticed that this figure tends to put out of reach the substantial dynamism of the market of Portuguese national dailies, which has suffered important changes in the last decade. First, the newspapers Correio da Manhã and Record, which have a leading position in the market, were previously controlled by "Presslivre" but they have been acquired by "Cofina" in 2000, which later launched the freely distributed newspaper Destak. Afterwards, a new important change affected the industry, with the newspapers 24 Horas, Jornal de Notícias, and Diário de Notícias being sold to Controlinveste Media in 2005. The following figure represents the graphic evolution of the aggregated market shares of the media groups participating in the market of national daily Portuguese newspapers, clearly showing the dominance of Cofina and Controlinveste (with several oscillations between them) and Media Capital only until 2009, with its main asset (the newspaper Metro) in the newspapers sector was sold to the company Cofina Media, SGPS, SA (associated with Cofina Group).

At the light of the data in Table 3 (in Appendix) and Figure 1, we can consider that the Portuguese newspaper industry exhibits a considerable degree of concentration, as a reduced number of media groups seem to control a significant part of the market. However, to evaluate such hypothesis more seriously and rigorously assess the degree of concentration of the market of national daily Portuguese newspapers, concentration measures should be computed. In this context, Table 4 reveals the extent of concentration in the industry of national daily Portuguese newspapers (in terms of average circulation), depicting the evolution of three concentration indicators (CR4, HHI and Noam index) for the period 2004-2013.

The concentration indexes depicted on Table 4 reveal that the market of Portuguese national dailies is highly concentrated. Despite some variations in the period between 2004 and 2013, in which the level of concentration has not changed significantly, Table 4 shows that the concentration indexes in the market of 
national daily Portuguese newspapers are relatively high, with $(i)$ the CR being higher than $90 \%$ for the whole period, (ii) the HHI being higher than 1,800 and, therefore, representing a highly concentrated market at the light of the US Department of Justice's antitrust enforcement guidelines; and (iii) the Noam Index being higher than 1,000 for the whole period.

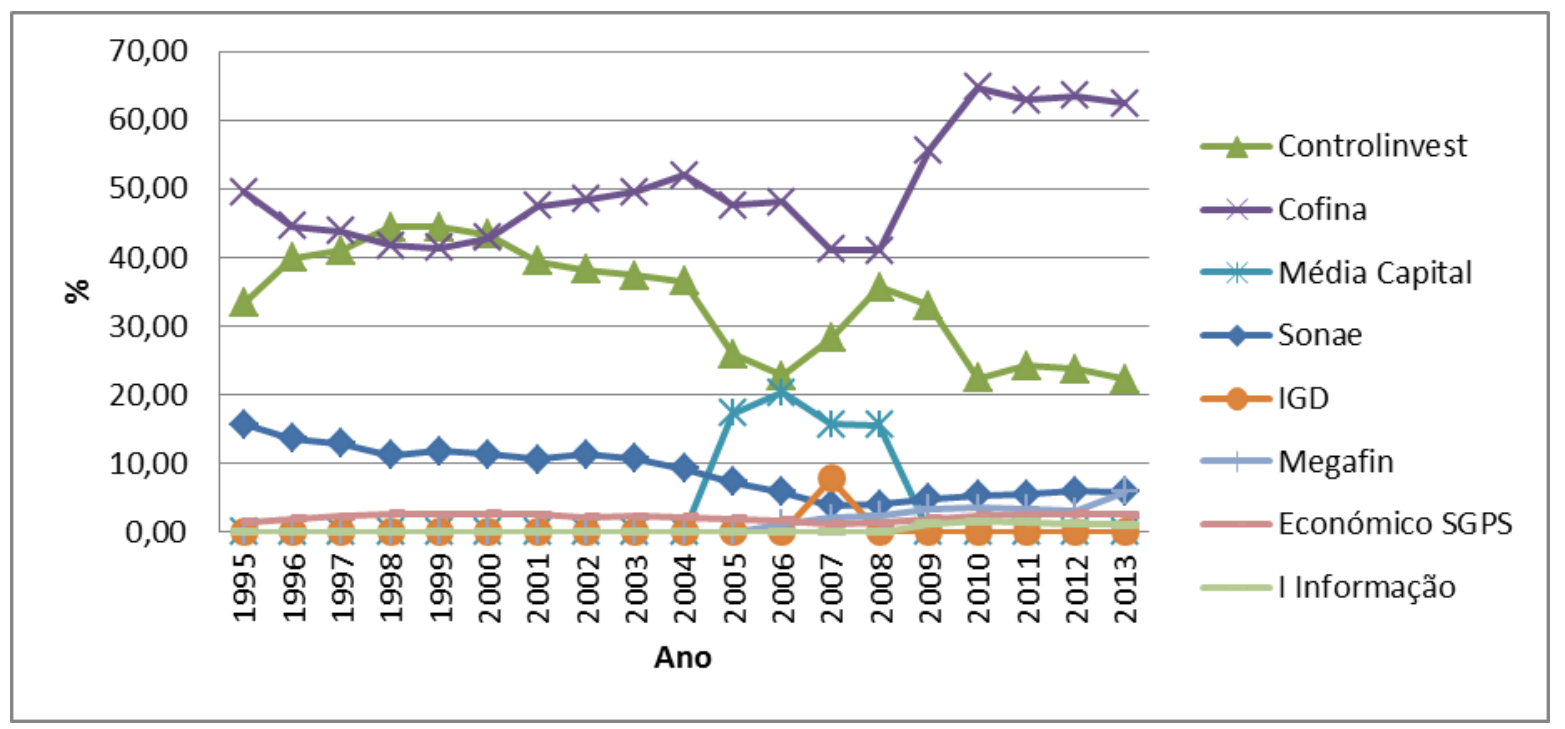

Figure 1. Aggregated market shares of the media groups participating in the market of national daily Portuguese newspapers. Source: Elaborated by the author based on data from APCT.

Table 4

CR4, HHI and Noam Indexes for National Newspaper Industry (2004-2013)

\begin{tabular}{lllllllllll}
\hline & 2004 & 2005 & 2006 & 2007 & 2008 & 2009 & 2010 & 2011 & 2012 & 2013 \\
\hline $\mathrm{N}(>1 \%)$ & 4 & 5 & 7 & 7 & 7 & 6 & 6 & 6 & 6 & 6 \\
$\mathrm{CR} 4$ & $100 \%$ & $98 \%$ & $97 \%$ & $89 \%$ & $96 \%$ & $97 \%$ & $96 \%$ & $96 \%$ & $96 \%$ & $96 \%$ \\
HHI & $4,127,71$ & $3,291,62$ & $3,284,31$ & $2,754,29$ & $3,212,70$ & $4,227,93$ & $4,745,06$ & $4,601,48$ & $4,644,81$ & $4,469,01$ \\
Noam & $2,063,86$ & $1,472,06$ & $1,241,35$ & $1,041,02$ & $1,214,28$ & $1,726,04$ & $1,937,16$ & $1,878,55$ & $1,896,24$ & $1,824,47$ \\
\hline
\end{tabular}

Note. Source: Elaborated by the author based on data from APCT.

The high degree of concentration exhibited by the Portuguese industry of daily national newspapers is not all surprising given the specific features of the Portuguese market and the dominance exerted by Controlinveste and Cofina, who have significant shares of the circulation market. Indeed, given the small size of the Portuguese market $^{4}$ and the specific features of newspaper industries (where learning effects, economies of scale and economies of scope are very frequent), one would expect an endogenous tendency of concentration arising in the market of Portuguese national dailies. In this context, the existence of a certain level of concentration constitutes a sine qua non condition for the healthiness of the market of Portuguese national dailies 5 .

\footnotetext{
${ }^{4}$ Portugal has only about 10 millions of inhabitants and, furthermore, the population purchasing power is relatively limited, with Portugal being below the European average for a large number of social and economic indicators.

${ }_{5}$ Under this subject, Faustino organized a study for the Portuguese Competition Authority where he addressed the need to study the sub segments of economic, free and regional newspapers to have the relevant market of the daily press in Portugal. The aforementioned study aimed to access the impact of the acquisition of Lusomundo Media by Controlinveste in the daily press market and if competition problems were foreseen. The conclusions were that no significant consequences in concentration terms could be foreseen and that the Portuguese market has some specifications, namely the importance of the weekly press, which guarantees the necessary pluralism of information.
} 
Despite the high absolute concentration levels exhibited by the market of Portuguese national dailies, the increase in the number of voices since 2005 seems to be contributing to reduce (though not very significantly) the degree of concentration in this market. In particular, the phenomenon of freely distributed newspapers has brought a new dynamic to the industry of Portuguese national dailies. Tough freely distributed newspapers are relatively recent phenomena, they already play an important role in the market of Portuguese dailies, obtaining higher market shares ${ }^{6}$ (both in terms of circulation and audience) than the most paid newspapers. On the one hand, the advent of freely distributed newspapers has created a "stealing market effect", with free newspapers capturing readers from paid newspapers. On the other hand, the introduction of the free press has contributed to expand the total size of the market, attracting new readers to the industry, namely younger and urban consumers. Summing up both effects, the total impact of freely distributed newspapers has been frankly positive, contributing (i) to increase total circulation (since freely distributed papers were able to countervail the decline in circulation of paid newspapers); (ii) to slightly reduce the concentration indexes (at least up to 2007); and (iii) to stimulate the pluralism and diversity of information by raising the number of active voices in the industry.

\section{Audiences}

In the previous section, the degree of concentration of Portuguese national dailies in terms of average circulation was assessed. However, to have a full picture of the extent of concentration in the Portuguese newspaper market (of daily periodicity and national coverage), this information should be completed with an analysis of concentration in terms of audiences, as one newspaper can, very often, be read by more than one person and, consequently, circulation data might not produce an accurate measure of the total impact of each newspaper. Furthermore, there is data on audiences for all newspapers participating in the market of Portuguese national dailies (including the newspaper "A Bola", which has been excluded from circulation analysis for lack of data). Table 5 depicts the audience shares for the daily newspapers of national coverage for the period 2004-2013.

Table 5 reveals that the dominance of Controlinveste and Cofina is relatively smaller in terms of audience shares than in terms of circulation. The reason for this seems to lie on the inclusion of the sports daily "A Bola", which was excluded from the previous analysis (for lack of data) despite its relevant market share. Accordingly, Table 5 seems to suggest an upward trend on the concentration indexes obtained for the average circulation. To confirm this hypothesis, the three concentration indexes (CR4, HHI and Noam index) have been recomputed using the companies' audience shares instead of teh average circulation. Results are summarized in Table 6 .

Table 6 confirms the previous hypothesis showing that all concentration indexes in terms of audience shares are lower than the corresponding concentration indexes in terms of average circulation. As already mentioned, the main reason for this discrepancy lies on the inclusion of the sports daily "A Bola". In any case, even when this newspaper is included in the analysis, concentration indexes remain significantly high, despite the decreasing tendency up to 2008. In a more longitudinal analysis, between 2005 and 2013, some oscillations are observed, with a slight tendency towards the reduction of concentration levels, depending on the audience analysis.

\footnotetext{
${ }^{6}$ According to the paper Trends in the Press Market and the State Support - The Portuguese Case and Experience, presented by Faustino in October 2008 in Hague, in a seminar organized by The Netherlands to Support the Press, in 2008, the Portuguese market share of freely distributed newspapers was, at that time, one of highest in Europe: 56, 95\%.
} 
Table 5

Audience Shares for the Daily Newspaper of National Coverage

\begin{tabular}{|c|c|c|c|c|c|c|c|c|c|c|}
\hline \% Audiências jornais & 2004 & 2005 & 2006 & 2007 & 2008 & 2009 & 2010 & 2011 & 2012 & 2013 \\
\hline Controlinveste & 39.33 & 37.93 & 34.92 & 31.25 & 27.86 & 30.00 & 29.57 & 29.22 & 30.04 & 31.28 \\
\hline 24 Horas & 5.04 & 4.80 & 4.46 & 4.08 & 3.76 & 3.87 & 0.00 & 0.00 & 0.00 & 0.00 \\
\hline Diário de Notícias & 6.39 & 5.88 & 4.75 & 4.85 & 5.01 & 5.47 & 4.97 & 5.44 & 5.61 & 6.15 \\
\hline O Jogo & 8.91 & 8.67 & 8.77 & 7.14 & 7.52 & 8.40 & 9.01 & 8.63 & 8.81 & 8.74 \\
\hline Jornal de Notícias & 18.99 & 18.58 & 16.94 & 15.18 & 15.32 & 16.13 & 15.59 & 15.14 & 15.62 & 16.39 \\
\hline Global Notícias & 0,00 & 0.00 & 0.00 & 0.00 & 7.10 & 4.67 & 0.00 & 0.00 & 0.00 & 0.00 \\
\hline Cofina & 34.45 & 36.69 & 35.36 & 38.27 & 40.53 & 48.00 & 48.25 & 47.54 & 45.93 & 43.44 \\
\hline Correio da Manhã & 16.97 & 15.79 & 13.82 & 15.31 & 15.88 & 16.53 & 17.74 & 18.86 & 18.69 & 19.26 \\
\hline Jornal Destak $\diamond$ & 1.51 & 5.42 & 8.02 & 9.82 & 10.58 & 7.33 & 7.12 & 5.71 & 4.94 & 3.42 \\
\hline Jornal de Negócios & 1.51 & 1.70 & 1.78 & 1.91 & 2.37 & 2.67 & 2.69 & 3.32 & 3.60 & 3.83 \\
\hline Record & 14.45 & 13.78 & 11.74 & 11.22 & 11.70 & 13.47 & 13.44 & 13.68 & 13.89 & 13.52 \\
\hline Metro Portugal & 0,00 & 0.00 & 0.00 & 0.00 & 0.00 & 8.00 & 7.26 & 5.98 & 4.81 & 3.42 \\
\hline Sonae & 8.91 & 7.89 & 6.69 & 5.99 & 6.13 & 6.00 & 5.91 & 6.77 & 6.81 & 7.79 \\
\hline Público & 8.91 & 7.89 & 6.69 & 5.99 & 6.13 & 6.00 & 5.91 & 6.77 & 6.81 & 7.79 \\
\hline Media Capital & 0,00 & 0.00 & 8.32 & 10.08 & 10.72 & 0.00 & 0.00 & 0.00 & 0.00 & 0.00 \\
\hline Metro Portugal & 0,00 & 0.00 & 8.32 & 10.08 & 10.72 & 0.00 & 0.00 & 0.00 & 0.00 & 0.00 \\
\hline Económica SGPS & 3.03 & 3.10 & 2.82 & 2.55 & 2.92 & 3.47 & 3.23 & 3.59 & 4.14 & 4.10 \\
\hline Diário Económico & 3.03 & 3.10 & 2.82 & 2.55 & 2.92 & 3.47 & 3.23 & 3.59 & 4.14 & 4.10 \\
\hline $\begin{array}{l}\text { Socied. Vicra } \\
\text { Desportiva, Lda }\end{array}$ & 14.29 & 14.40 & 11.89 & 11.86 & 11.84 & 12.53 & 13.04 & 12.88 & 13.08 & 13.39 \\
\hline A Bola & 14.29 & 14.40 & 11.89 & 11.86 & 11.84 & 12.53 & 13.04 & 12.88 & 13.08 & 13.39 \\
\hline Total & 100 & 100 & 100 & 100 & 100 & 100 & 100 & 100 & 100 & 100 \\
\hline
\end{tabular}

Note. Source: Elaborated by the author based on data from Marktest.

Table 6

Concentration Indexes for the Newspapers Portuguese Market

\begin{tabular}{lllllllllll}
\hline & 2004 & 2005 & 2006 & 2007 & 2008 & 2009 & 2010 & 2011 & 2012 & 2013 \\
\hline N $(>1 \%)$ & 5 & 5 & 6 & 6 & 6 & 5 & 5 & 5 & 5 & 5 \\
CR4 & $97 \%$ & $97 \%$ & $89 \%$ & $91 \%$ & $91 \%$ & $97 \%$ & $97 \%$ & $96 \%$ & $96 \%$ & $96 \%$ \\
IHH & $3,026.31$ & $3,063.48$ & $2,733.12$ & $2,725.49$ & $2,719.80$ & $3,409.10$ & $3,418.06$ & $3,338.62$ & $3,246.46$ & $3,122.63$ \\
Noam & $1,353.41$ & $1,370.03$ & $1,115.79$ & $1,112.68$ & $1,110.35$ & $1,524.60$ & $1,528.60$ & $1,493.08$ & $1,451.86$ & $1,396.48$ \\
\hline
\end{tabular}

Note. Source: Elaborated by the author based on data from Marktest.

\section{Advertising Revenues}

In the previous sections, the degree of concentration in the Portuguese market of national dailies from readers' perspective has been assessed, computing concentration measures in terms of newspapers' total circulation and audiences. Nevertheless, the newspaper industry constitutes a two-sided market, in the sense that newspapers' core business is developed in two distinct but interrelated markets: the circulation market (where newspapers sell content to readers) and the advertising market (where newspapers sell eyeballs to advertisers). Accordingly, to evaluate the extent of concentration in the market of Portuguese national dailies, the previous concentration measures must be complemented with concentration measures concerning the participation of newspapers in the advertising market. To this end, the author has collected data on newspapers' advertising revenues ${ }^{7}$ (see Table 7).

\footnotetext{
7 The data on newspapers' advertising revenues (based on newspapers' official ad-rates) was obtained from Marktest annual report on media and advertising for the year 2007.
} 
Table 7

Newspapers' Advertising Revenues at Official Ad-rates (Thousands of Euros)

\begin{tabular}{|c|c|c|c|c|c|c|c|}
\hline & 2007 & 2008 & 2009 & 2010 & 2011 & 2012 & 2013 \\
\hline Controlinveste & 132,961 & 147,211 & 138,839 & 114,243 & 108,084 & 114,360 & 109,233 \\
\hline 24 Horas & 13,434 & 13,604 & 15,574 & 7,114 & - & - & - \\
\hline Diário de Notícias & 39,211 & 40,018 & 35,368 & 32,417 & 36,286 & 36,298 & 34,871 \\
\hline O Jogo & 7,104 & 7,899 & 7,597 & 7,507 & 9,303 & 11,894 & 12,231 \\
\hline Jornal de Notícias & 70,015 & 68,775 & 64,183 & 59,400 & 62,495 & 66,168 & 62,131 \\
\hline Global Notícias & 3,197 & 16,915 & 16,117 & 7,805 & - & - & - \\
\hline Cofina & 120,464 & 129,771 & 146,679 & 137,752 & 133,180 & 139,187 & 134,697 \\
\hline Correio da Manhã & 64,208 & 65,334 & 60,379 & 59,447 & 59,525 & 63,558 & 65,123 \\
\hline Jornal Destak $\diamond$ & 32,863 & 40,671 & 31,277 & 27,451 & 23,724 & 20,459 & 17,658 \\
\hline Jornal de Negócios & 8,369 & 9,050 & 11,244 & 13,287 & 14,669 & 15,069 & 13,919 \\
\hline Record & 15,024 & 14,716 & 17,550 & 18,030 & 15,495 & 20,696 & 21,333 \\
\hline Metro Portugal & - & - & 26,229 & 19,537 & 19,767 & 19,405 & 16,664 \\
\hline Sonae & 34,736 & 31,340 & 27,687 & 25,556 & 22,329 & 19,339 & 20,127 \\
\hline Público & 34,736 & 31,340 & 27,687 & 25,556 & 22,329 & 19,339 & 20,127 \\
\hline Media Capital & 29,015 & 28,984 & - & - & - & - & - \\
\hline Metro Portugal & 29,015 & 28,984 & - & - & - & - & - \\
\hline Económica SGPS & 19,712 & 21,177 & 20,503 & 31,274 & 32,809 & 31,445 & 30,554 \\
\hline Diário Económico & 19,712 & 21,177 & 20,503 & 31,274 & 32,809 & 31,445 & 30,554 \\
\hline $\begin{array}{l}\text { Socied. Vicra } \\
\text { Desportiva, Lda }\end{array}$ & 9,630 & 10,844 & 15,550 & 15,946 & 14,746 & 10,169 & 8,673 \\
\hline A Bola & 9,630 & 10,844 & 15,550 & 15,946 & 14,746 & 10,169 & 8,673 \\
\hline Total & 346,518 & 369,327 & 349,258 & 324,771 & 311,148 & 314,500 & 303,284 \\
\hline
\end{tabular}

Notes. The newspapers OJE and Diário Desportivo, both active in the market in 2007 were excluded for lack of data ${ }^{8} ; \diamond$ Aggregated advertising revenues (including Lisboa, Porto and other national editions). Source: Elaborated by the author based on data from Marktest.

Considering advertising revenues in Table 7, newspapers' market shares in the advertising market (by newspaper and by media group) are reproduced on Table 8 .

Tables 6 and 7 reveal that advertising revenues in the market of Portuguese national dailies are highly concentrated on two media groups: "Controlinveste" and "Cofina". Therefore, the situation of the advertising market seems to mimic the outcomes of the circulation market, which is not all a surprise, given the interrelations between circulation and advertising markets: advertisers are seeking for "eyeballs" and, consequently, the larger the newspaper's circulation/audiences, the more attractive this newspaper becomes to advertisers (gaining larger advertising revenues). In this context, given the high degree of concentration of the circulation market, it is expectable to observe a highly concentrated newspaper industry in terms of advertising revenues. To confirm the validity of this hypothesis, the concentration indexes (CR4, HHI and Noam index) have been computed and reproduced in Table 9.

Results in Table 9 confirm that the advertising market is highly concentrated (reflecting very closely the situation of the market of the Portuguese national dailies in terms of average circulation or audiences). However, it should be stressed that in the case of advertising market, Portuguese national dailies face direct

\footnotetext{
8 The exclusion of these two newspapers shall not introduce a significant bias on the concentration estimates. Indeed, these newspapers capture a very small fraction of the press advertising revenues (and for this reason they are excluded from an autonomous analysis by Marktest that publishes exclusively the advertising revenues of the 50 major press outlets-newspapers and magazines.
} 
competition from weekly dailies with a long tradition and readership in Portugal, as well as regional (daily or weekly) newspapers. While in the case of the circulation market there is a rationale to exclude weekly press from the relevant market (given the different timing), in the case of the advertising revenues, these differences are less evidence since, from the viewpoint of advertisers, all types of media outlets are offering "eyeballs to advertisers". Accordingly, the actual levels of concentration in the advertising market (when this is considered from a broader but more realistic perspective) should be smaller as a result of the competitive pressure exerted by other players like Expresso that have a very important position in the advertising market.

Table 8

Newspapers' Market Shares in the Advertising Market (\%)

\begin{tabular}{|c|c|c|c|c|c|c|c|}
\hline & 2007 & 2008 & 2009 & 2010 & 2011 & 2012 & 2013 \\
\hline Controlinveste & $38.37 \%$ & $39.86 \%$ & $39.75 \%$ & $35.18 \%$ & $34.74 \%$ & $36.36 \%$ & $36.02 \%$ \\
\hline 24 Horas & $3.88 \%$ & $3.68 \%$ & $4.46 \%$ & $2.19 \%$ & 0 & 0 & 0 \\
\hline Diário de Notícias & $11.32 \%$ & $10.84 \%$ & $10.13 \%$ & $9.98 \%$ & $11.66 \%$ & $11.54 \%$ & $11.50 \%$ \\
\hline O Jogo & $2.05 \%$ & $2.14 \%$ & $2.18 \%$ & $2.31 \%$ & $2.99 \%$ & $3.78 \%$ & $4.033 \%$ \\
\hline Jornal de Notícias & $20.21 \%$ & $18.62 \%$ & $18.38 \%$ & $18.29 \%$ & $20.09 \%$ & $21.04 \%$ & $20.49 \%$ \\
\hline Global Notícias & $0.92 \%$ & $4.58 \%$ & $4.61 \%$ & $2.40 \%$ & 0 & 0 & 0 \\
\hline Cofina & $34.76 \%$ & $35.14 \%$ & $42.00 \%$ & $42.42 \%$ & $42.80 \%$ & $44.26 \%$ & $44.41 \%$ \\
\hline Correio da Manhã & $18.53 \%$ & $17.69 \%$ & $17.29 \%$ & $18.30 \%$ & $19.13 \%$ & $20.21 \%$ & $21.47 \%$ \\
\hline Jornal Destak $\diamond$ & $9.48 \%$ & $11.01 \%$ & $8.96 \%$ & $8.45 \%$ & $7.62 \%$ & $6.51 \%$ & $5.82 \%$ \\
\hline Jornal de Negócios & $2.42 \%$ & $2.45 \%$ & $3.22 \%$ & $4.09 \%$ & $4.71 \%$ & $4.79 \%$ & $4.59 \%$ \\
\hline Record & $4.34 \%$ & $3.98 \%$ & $5.02 \%$ & $5.55 \%$ & $4.98 \%$ & $6.58 \%$ & $7.03 \%$ \\
\hline Metro Portugal $\diamond$ & 0 & 0 & $7.51 \%$ & $6.02 \%$ & $6.35 \%$ & $6.17 \%$ & $5.49 \%$ \\
\hline Sonae & $10.02 \%$ & $8.49 \%$ & $7.93 \%$ & $7.87 \%$ & $7.18 \%$ & $6.15 \%$ & $6.64 \%$ \\
\hline Público & $10.02 \%$ & $8.49 \%$ & $7.93 \%$ & $7.87 \%$ & $7.18 \%$ & $6.15 \%$ & $6.64 \%$ \\
\hline Media Capital & $8.37 \%$ & $7.85 \%$ & 0 & 0 & 0 & 0 & 0 \\
\hline Metro Portugal $\diamond$ & $8.37 \%$ & $7.85 \%$ & 0 & 0 & 0 & 0 & 0 \\
\hline Económica SGPS & $5.69 \%$ & $5.73 \%$ & $5.87 \%$ & $9.63 \%$ & $10.54 \%$ & $10.00 \%$ & $10.07 \%$ \\
\hline Diário Económico & $5.69 \%$ & $5.73 \%$ & $5.87 \%$ & $9.63 \%$ & $10.54 \%$ & $10.00 \%$ & $10.07 \%$ \\
\hline $\begin{array}{l}\text { Socied. Vicra } \\
\text { Desportiva, Lda }\end{array}$ & $2.78 \%$ & $2.94 \%$ & $4.45 \%$ & $4.91 \%$ & $4.74 \%$ & $3.23 \%$ & $2.86 \%$ \\
\hline A Bola & $2.78 \%$ & $2.94 \%$ & $4.45 \%$ & $4.91 \%$ & $4.74 \%$ & $3.23 \%$ & $2.86 \%$ \\
\hline Total & $100 \%$ & $100 \%$ & $100 \%$ & $100 \%$ & $100 \%$ & $100 \%$ & $100 \%$ \\
\hline
\end{tabular}

Notes. The newspapers OJE and Diário Desportivo, both active in the market in 2007 were excluded for lack of data9. $\diamond$ Aggregated advertising revenues (including Lisboa, Porto and other national editions). Source: Elaborated by the author based on data from Marktest.

Table 9

Concentration Indexes for the Newspapers Portuguese Market

\begin{tabular}{llllllll}
\hline & 2007 & 2008 & 2009 & 2010 & 2011 & 2012 & 2013 \\
\hline C4 & $91.53 \%$ & $91.33 \%$ & $95.55 \%$ & $95.09 \%$ & $95.26 \%$ & $96.77 \%$ & $97.14 \%$ \\
IHH & 2,892 & 2,998 & 3,461 & 3,215 & 3,224 & 3,429 & 3,423 \\
Noam & 1,180 & 1,224 & 1,548 & 1,438 & 1,442 & 1,534 & 1,531 \\
\hline
\end{tabular}

Note. Source: Elaborated by the author using data from Marktest.

\footnotetext{
9 The exclusion of these two newspapers shall not introduce a significant bias on the concentration estimates. Indeed, these newspapers capture a very small fraction of the press advertising revenues (and for this reason they are excluded from an autonomous analysis by Marktest that publishes exclusively the advertising revenues of the 50 major press outlets - newspapers and magazines).
} 


\section{Conclusions and Future Directions}

The media activity develops between two poles representing commercial and cultural orientations. Therefore, economic competition within the media sector is always well received, when considering the benefits it brings to society. Concentration may represent a corporate defense mechanism, used by companies in order to be able to face strong competition scenarios. Within this scope, the subject of media concentration needs, in certain situations, to be analyzed in the absence of any dogmas relative to the importance of economic aspects, but from the standpoint where it enables the existence of a wider and more diverse media offer. Notwithstanding the different possible perspectives of media concentration studies, our research focuses more on a single media approach, by considering the case of press in particular. Despite the existing limitations of a single media perspective, this was considered a good starting point, by allowing us to establish more concrete and objective ideas regarding the real power of information market groups, for developing a more in-depth research on the subject of multimedia concentration. An important aspect that should be taken into account in the beginning of any media concentration study relates to the kind of segment (support) under analysis. In this sense, it is possible to conclude that the concentration concept is not as general as might be believed, as most differences observed between the various media types occur between audiovisual media and the press.

Media companies are exposed to a constant process of change, due to important observable modifications within its sphere of influence. For these companies, information is both the raw material and the final product; treatment of information is the process undergoing the most profound modifications: renovation and technological convergence towards digital supports, consumer taste and lifestyle alterations, emergence of new information supports and players and strategic alliance and merger processes between companies. In this context, the main research question in the present study is: What is the current degree of press concentration in Portugal? Associated to this broad question, more specific approaches may be asked, namely: i) Has the media sector in Portugal been undergoing a concentration process? ii) Are main press group market shares high? So, this research permitted essay to preliminary answers to this questions. Furthermore, despite the considerable degree of market power of these media groups and his presence in daily newspaper segment, it should be stressed that very hardly these groups can abuse from their dominant position in the market of Portuguese national dailies, since:

- Barriers to entry are relatively limited (in contrast with the case of radio or TV, in the case of press there exists freedom of entry). Even entry costs in newspaper industry are relatively high ${ }^{10}$, the legal possibility of free entry limits the discretionary power of incumbent firms. In fact, the freedom of entry creates endogenous market mechanisms to limit incumbents' exploitation of market power because the observance of significant supernormal profits ${ }^{11}$ will attract new newspapers to the market In the case of the Portuguese market of national dailies, the entry mechanism seems to be working quite well (and the boom of freely distributed newspapers constitutes a good example of it; and until March (2009) will be launch by Sojormedia - Grupo Lena - a new national daily newspaper with general information).

- In Portugal these exists an important tradition of national weekly newspaper like Expresso, Sol, and also weekly magazines like Visão or Sábado. These outlets end up having a central role on the market of Portuguese

\footnotetext{
${ }^{10}$ In the case of daily newspapers, entry costs are relatively higher than the entry costs in other market segments of the press industry (e.g., magazines or regional weekly press), which can be classified as contestable markets.

${ }^{11}$ Since entry is costly (namely in terms of fixed and sunk costs), supernormal profits must be above a certain threshold in order to make entry strategies profitable.
} 
newspapers, exerting a competitive pressure in the market of national dailies ${ }^{12}$.

- In Portugal, there exists as well an important tradition of reading weekly newspapers of regional and local coverage like for example: Mirante, Região de Leiria, and Jornal do Fundão. Again, these newspapers despite not being included in the market of Portuguese national daily newspapers end up exerting a competitive pressure over this market.

Despite not being the main objective of this research, it should be mentioned that one of the central issues related to concentration is not whether this realty should be prevented-since it is unavoidable and may, in certain aspects, be considered as a positive element — but to determine its limits and boundaries. These boundaries depend on many factors, such as dimension, consumer ability and economic situation of a particular country or region. For example, in smaller countries, such as Portugal, higher levels of concentration tend to exist naturally, since reduced market dimensions do not favor distribution of media products by several companies. The concentration issue should not solely be analyzed from a property concentration perspective; information access opportunities should also be considered. If we consider that information diversity relates to media offer and diversity, it is possible to conclude that, simultaneously with the trend for property concentration - unavoidable in a small country such as Portugal—observed in the last 10 years (and especially in the last four years), media offer and diversity have undergone an exponential growth, in the various media segments.

Even if the facts analyzed in this paper do not allow us to conclude that existing a newspaper concentration levels in Portugal constitute a threat to information diversity, this does not necessarily mean that media concentration situations that may constitute cause for concern will not occur. Despite not being the main purpose of this research (Faustino, 2008, 2009; Ribeiro, 2007), it is known that some situations in Portugal correspond to concentration levels that have negative effects on the market and Portuguese society, namely:

- Advertising investment concentration in television (circa 70\%);

- Radio sector concentration (dominated by Renascença and Media Capital, with circa $60 \%$ of advertising market);

- Infrastructure concentration within the cable business (Zon holds more than $80 \%$ of the market).

The occurrence of new mergers does not necessarily mean a reduction in information diversity. Media concentration may have positive or negative impacts, depending on the country's social and economic situation. Allowed concentration limits should consider the market as a whole - that is to say, a coherent definition of the relevant market. In small countries, such as Portugal, this limit may be-in order for certain projects to be economically viable - slightly superior to those agreed for larger markets or countries ${ }^{13}$.

Media concentration in general and newspaper concentration in Portugal should be analyzed from a broader perspective and not only from a dogmatic perspective has that placed all emphasis on negative effects. Sector analysis should be included in a multimedia context instead of focusing on a particular press segment. As stated by Faustino (2001) “... property concentration may lead to new market development possibilities, by

\footnotetext{
12 At this purpose, investigating this question with an econometric perspective, Joel Waldfogel of University of Pennsylvania, in a study for the FCC, looked at consumer substitution between several media. He found that substitution effect exists between Internet and broadcasting TV; between daily and weekly newspapers; between daily newspaper and broadcast TV news; between cable and daily newspapers; between radio and broadcast and TV for news; and between Internet and daily newspaper for news. He did not find such substitution between weekly newspaper and broadcast TV, or between radio and either Internet or cable (in Noam, Media Ownership and Concentration in America, 2009).

${ }^{13}$ Concerning this subject, Paulo Fernandes considers that: “... the entire world is witnessing increasing media concentration... in order to ensure business profitability, it is necessary to gain dimension and market share”, Meios magazine, p. 3, April of 2002.
} 
increasing employee career opportunities and financial resources, as well as the ability to conceive and launch new means of communication, on a scale and with a frequency that would have been beyond imagination a few years ago" (p. 50).

Given the high level of investment needed, some media products can only be developed by large groups (not necessarily media groups). For example, in the press sector, news magazines (such as Sábado and Visão) require high investments, which are why they are included in media groups, the same occurring with national daily newspapers ${ }^{14}$. The idea that an economic group operating mainly in the media business (thus entirely dependent on advertising investment) has an increased competitive advantage (due to the synergies it may develop between different media supports) over groups operating in several sectors (not only the media sector), is highly questionable. Media business growth is increasingly based on financial capacity to face adverse economic cycles and ability to take advantage of other promotion and distribution channels. Given this, competition analysis should also consider this group's potential businesses in other fields. When considering the positive effects of concentration, three aspects should be mentioned:

- Access to new resources and information technology sources, as well as the possibility of developing new supports. In this perspective, concentration decreases difficulties in implementing new technologies within the press sector, since the company in question may use these new technologies for other sectors;

- Avoidance of a potential State Monopoly within the information field. This is the reason behind the concept of functional concentration, expressed in Vedel's report (1970): "functional concentration, based on cooperation instead of domination, may be a necessary condition for survival of information diversity and the press itself, in a more or less distant future";

- Improvement in information quality, especially within certain areas. We should like to draw your attention to the relative value of these effects, which are never isolated, often entailing negative consequences.

Analysis of the various indicators developed in order to quantify some variables relative to the concentration levels of Portuguese media groups, especially within the press sector, allow us to conclude that evaluation of group ability to influence the press market should take into account its presence in the total general information segment and not only the daily general information segment. Even if analysis of the Tables presented in this paper allows us to conclude that a significant concentration level exists in the Portuguese press sector (this having now been the case for a few years), it does not allow us to conclude that this level of concentration is compromising information diversity or market competitiveness levels. On the contrary, Portuguese media sector dynamics in the past 10 years may have contributed to an increase in information diversity, attributable to an increased information offer. This does not rule out the possibility that at given points in time, but not structurally, information pluralism may be questioned. As such, it is important to identify and monitorise those moments and the role played by the regulatory entities, such as the Media Regulatory Entity (content regulation) and the Competition Authority (regulating the market). Notwithstanding, it should be said that the application of competition rule by itself does not guarantee pluralism and free of speech.

The press concentration may assume several forms, namely, (1) Progressive appropriation of private sector media, resulting from the association of different organizations to this sector and the growing importance of certain financial groups, which extend their activity to several sectors; (2) Extension of company activity to

\footnotetext{
${ }^{14}$ Newspaper Public constitutes a paradigm of the need to be integrated into a group with sufficient financial capacity: for many years, this newspaper presented no profits, having only reached break-even in 2002. If not for the financial capacity of the owner group, this newspaper would have disappeared a long time ago.
} 
various information fields (news, cultural products, elaboration of communication materials); (3) Increase in the number and importance of regional information chains and editions, as well as concentration of newspapers and other publications within the same company; and (4) Mergers between newspapers and distribution companies, as well as press control by other industrial sectors and banks.

As final conclusion, we can consider that in the case of the Portuguese daily press market, the term concentration should be replaced by consolidation. Certain management movements executed by means of mergers and acquisitions can generate consolidation but not always create concentration situations. In what concerns the case analyzed in this paper, it cannot be concluded that the observed consolidation movements are obstructing the free competition in the sector. Notwithstanding, the financial situation of media companies, and of newspapers in particular, has been degrading, reaching almost unbearable situations during 2008, in a context of international economic crisis ${ }^{15}$. This circumstance is, sometimes, a pressure factor for resources optimization and for the adoption of strategies that lead to concentration and consolidation processes that signify the survival of organizations. In this context, Noam (2009), suggest eventually, some competitors fail, others consolidate, and the industries reconcentrate. Prices rise again and higher profits return, this attract new entrants, and a new cycle begins.

It can even be that a certain concentration level benefits the market and the information consumers. The question is to define boundaries, which differ according to each operation context. Market dimension is a fundamental factor to take into account in media concentration studies. Notwithstanding the data here analyzed about media concentration in Portugal namely in the daily press sector, suggest some concentration-inevitable in such a small country - but does not allow to conclude that the current concentration scenario is jeopardizing pluralism and free of speech. It is however, clear that it is necessary to find a new model to measure concentration and pluralism in the media sector, as traditional models (like HHI and CR4, for example) are not adequate. The problem with the $\mathrm{HHI}$ and the $\mathrm{C} 4$ is that although market power is considered they do not address pluralism, which is also essential. In fact, those indicators only look at actual choices rather than options, neglecting diversity. And in this context, the Noam Index model will be a very good contribution to improve the analyses of media concentration and pluralism, as the Media Ownership and Diversity Concentration Index (MOCDI, or Noam index) normalizes the HHI by taking into account the number of voices available in the market.

Surely, there is no such thing as perfect models and sometimes market power can demur from an easy access to the advertising market enabled by the integration in economic groups (conglomerates) that are simultaneously the most important advertisers (e.g., telecommunications, banking and retail players). Existing index and models do not allow the verification of crossed interests and respective competitive advantages. This is particularly important, as the overall media market, and press in particular, still shows a considerable weight of advertising in total revenues ${ }^{16}$. As such, it is important to analyze how the connection between newspapers publishers and big advertising investors can be reflected into a dominant market power, or, using a pluralism

\footnotetext{
15 Regarding this subject, in a 2009 report made by Media XXI, coordinated by Paulo Faustino, for the Portuguese Regulatory Communication Entity (The Economic and Financial Situation of the Press), after analyzing seven newspapers publishers, the poor financial performance of the Portuguese press was translated by operational margins over revenues between $6.3 \%$ and $7.3 \%$. These results compare with J.P. Morgan findings that referred peers' EBITDA margins between 21\% and $29 \%$.

${ }^{16}$ According to Faustino (2010) in Portugal, advertising represents more than 50\% of total revenues in newspaper companies. See also at this purpose Anderson, S., \& Gabszewicz, J. (2006), The media and advertising: A tale of two-sided markets, in Ginsburgh, V., \& Throsby, D., 2006, Handbook of the Economics of Art and Culture, volume 1, Amsterdam: North-Holland.
} 
approach, how such connections influence contents.

Crossed shareholdings (or other relations) will surely be focused by future research studies and analysis models. Media companies, with traditional business models very dependent on advertising have opened their share capital to shareholders from other economic sectors to finance activities and increase competitiveness. Now they are exposed to economic and social forces which, directly or indirectly can pressure the corporation decisions. Media products are in their majority the result of privately owned companies and it is possible that business partners (of which the companies depend) tempt to influence contents. Notwithstanding, such analysis should be done avoiding a dogmatic approach, which can also signify, from an economic point of view, to understand the leading reasons for consolidation and concentration strategies. Concentration analysis should not be reduced to the choice of a good market share measurement index, and it might be interesting to cross measurement indexes with the analysis of editorial content.

\section{References}

Albarran, A. (2004). Responsabilidade ou Cegueira Estratégica? (Responsibility or Strategic Blindness?). In Media XXI (pp. 90-91). Lisboa: MediaXXI.

Albarran, A. et al. (2005). Handbook of media management and economics. London: Lawrence Erlbaum Associates, Publishers.

Associação Portuguesa de Controlo de Tiragem. (2009). Boletins Trimestrais da Circulação Média da Imprensa (Quarterly Newsletters of Press Average Circulation). Lisboa: APCT.

Bogart, L. (2000). Commercial culture. USA: Transaction Publishers.

Compaine, B. (2005). The vanishing digital divide. In A. Zerdick et al. (Eds.), E-merging media: Communication and the media economy of the future. New York: Springer.

Faustino, P. (2008). Economia, Gestão e Concentração dos Media: tendências e Dinâmicas da Imprensa num Contexto Multimédia (Economics, management and the media concentration: Trends and dynamics of media in multimedia context). Tese de Doutoramento no Departamento de Periodismo IV/Empresa formativa, Universidade Complutense de Madrid/Spain.

Faustino, P. (2009). Tendências e Prospectiva dos Media: Inovação, Gestão, Emprego e Mercado (Trends and media prospects: innovation, management, employment and market). Lisbon: MediaXXI.

Garnham, N. (1990). Capitalism and communications: Global culture and economics of information. London: Sage.

Gustafsson, K. (1995). Media structure and the state: Concepts, issues, measures. Suécia: Gotebeorg University.

Iglesias, F. (2005). Concentración y Pluralismo en la Rádio Española (Concentration and Pluralism in the Spanish Rádio). Pamplona: Eunsa.

Jones, C. (2005). Winning with the news media-A self-defense manual when you're the story. Anna Maria: Winning news media (Florida).

Marktest. (2009). Anuário da Comunicação e Publicidade (Communication and Advertising Yearbook). Lisboa: Edição Marktest.

Marx, K. (1968). O Capital-crítica da economia política (The Capital-Critique of political economy). Lisboa: Editora da Civilização Brasileira.

McChesney, R. (2000). Rich media, poor democracy: Communication politics in Dubious Times. New York: The New Press.

Mosco, V. (1996). The political economy of communication: Rethinking and renewal. London: Thousand Oaks, Sage.

Nieto, A., \& Mora, J. (1989). Concentración informative en Espanã: prensa diária (Informative concentration in Spain: Daily Press). Pamplona: Universidade Navarra.

Noam, E. (2009). Media ownership and concentration in American. UK: Oxford University Press.

Picard, R. (2002a). The economics and financing of media companies. New York: Fordham University Press.

Picard, R. (2002b). Media firms: Structures, operations and performance. Mahwah, N.J.: Erlbaum.

Picard, R., Winter, J., McCombs, M., \& Lacy, S. (1988). Press concentration and monopoly: New perspectives on newspaper ownership and operation. Norwood, N.J.: Ablex.

Report Vedel. (1972). Report of the Working Party examining the problem of the enlargement of the powers of the European Parliament. Retrieved from http://www.ena.lu/vedel-report-25-march-1972-020002255.html

Ribeiro, L. (2007). A Televisão Paga: Dinâmicas de Mercado em Portugal e na Europa (The payd TV: Market dynamics in Portugal and Europe). Lisboa: MediaXXI. 
Tabernero, S. (1993). Media concentration in Europe-Commercial enterprise and the public interest. Düsseldorf: The European Institute for the Media.

Tallón, J. in Táuler y José Ignácio Población. (2000). Estudios de Empresa Informativa. Homenaje al Profesor José Tallón (Informative Business Studies: Tribute to Professor Joseph Tallon). Madrid: Universidad Complutense.

Táuler, M., \& Población, J. (2000). Estudios de Empresa Informativa (Informative business studies). Madrid: Departamento de Periodismo IV (Empresa Informativa) de la Universidad Complutense.

Toussaint, N. (1979). La economía de la información (Information economics). Barcelona: Oikos-Tau.

Van Cuilemburg, J. (2003). Media between commerce and culture, openning conference media management and transformation centre. Sweden: Jibs Reports, Jonkonping University. 


\section{Appendix}

Table 2

Daily Average Circulation for Portuguese Newspapers 1995-2013

\begin{tabular}{|c|c|c|c|c|c|c|c|c|c|c|c|c|c|c|c|c|c|c|c|}
\hline & 1995 & 1996 & 1997 & 1998 & 1999 & 2000 & 2001 & 2002 & 2003 & 2004 & 2005 & 2006 & 2007 & 2008 & 2009 & 2010 & 2011 & 2012 & 2013 \\
\hline \multicolumn{20}{|l|}{ Controlinvest } \\
\hline 24 Horas & & & & 21,577 & 21,420 & 25,019 & 32,061 & 39,505 & & & & & & & & & & & \\
\hline Diário de Notícias & 44,055 & 44,903 & 45,015 & 51,965 & 57,439 & 69,154 & 61,119 & 53,747 & 50,794 & 42,699 & 37,992 & 37,904 & 37,759 & 45,270 & 34,181 & 30,670 & 35,294 & 29,332 & 21,931 \\
\hline Global Noticias & & & & & & & & & & & & & 150,575 & 203,480 & 104,955 & & & & \\
\hline O Jogo & & 34,456 & 39,674 & 39,055 & 38,264 & 38,862 & 37,391 & 34,837 & 40,677 & 49,809 & 44,878 & 41,473 & 35,976 & 32,786 & 30,037 & 29,945 & 28,396 & 23,891 & 23,536 \\
\hline Jornal de Notícias & 80,475 & 83,055 & 81,298 & 105,187 & 108,221 & 104,919 & 106,978 & 108,659 & 105,242 & 115,960 & 98,637 & 97,459 & 93,916 & 103,177 & 90,964 & 86,511 & 87,122 & 74,709 & 67,508 \\
\hline \multicolumn{20}{|l|}{ Cofina } \\
\hline Jornal Destak & & & & & & & 35,000 & 45,044 & 53,567 & 71,479 & 118,803 & 169,923 & 172,261 & 162,132 & 104,258 & 111,643 & 94,669 & 78,508 & 73,274 \\
\hline Jornal de Negócios & & & & 9,779 & 11,081 & 12,279 & 12,070 & 9,938 & 7731 & 10,468 & 8,890 & 8,106 & 8,261 & 9,338 & 10,675 & 10,530 & 10,540 & 10,559 & 10,449 \\
\hline Record & 103,518 & 101,864 & 101,599 & 101,403 & 100,080 & 104,486 & 97,948 & 92,869 & 84,889 & 94,465 & 86,964 & 79,768 & 76,582 & 73,872 & 72,560 & 70,721 & 63,464 & 56,256 & 52,526 \\
\hline Meia Hora & & & & & & & & & & & & & 86,496 & 74,893 & 23,301 & & & & \\
\hline Metro Portugal & & & & & & & & & & & & & & & 105,660 & 105,062 & 93,646 & 73,646 & 62,888 \\
\hline
\end{tabular}

$12,1134 \quad 158,037 \quad 176,357 \quad 167,758$

Metro Portugal

Sonae

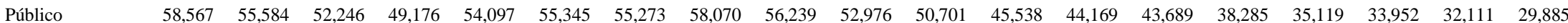

IGD

Diário Desportivo

87,818

Megafin

OJE

Económico SGPS

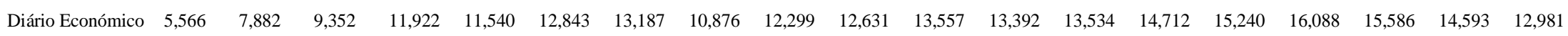
I Informação

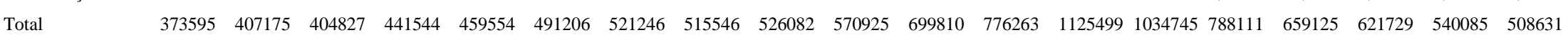

Notes. Newspaper segments: 1 = General Information, 2 = Free Distribution, 3 = Sports, 4 = Economics; Source: APCT; Diário Desportivo was distributed in 2007 only.

Up to 2005, the newspapers "24 Horas", "Jornal de Notícias" and "Diário de Notícias" were under Lusomundo Media/ Portugal Telecom control, before Controlinveste acquired them. 
Table 3

Evolution of Market Shares for Portuguese Newspaper Companies (1995-2013)

\begin{tabular}{|c|c|c|c|c|c|c|c|c|c|c|c|c|c|c|c|c|c|c|c|}
\hline Shares de mercado & 1995 & 1996 & 1997 & 1998 & 1999 & 2000 & 2001 & 2002 & 2003 & 2004 & 2005 & 2006 & 2007 & 2008 & 2009 & 2010 & 2011 & 2012 & 2013 \\
\hline & $\%$ & $\%$ & $\%$ & $\%$ & $\%$ & $\%$ & $\%$ & $\%$ & $\%$ & $\%$ & $\%$ & $\%$ & $\%$ & $\%$ & $\%$ & $\%$ & $\%$ & $\%$ & $\%$ \\
\hline Controlinvest & 33,33 & 39,89 & 41,00 & 44,44 & 44,37 & 43,35 & 39,42 & 38,26 & 37,39 & 36,51 & 25,94 & 22,78 & 28,27 & 35,62 & 33,01 & 22,32 & 24,26 & 23,69 & 22,21 \\
\hline Cofina & 49,50 & 44,53 & 43,78 & 41,73 & 41,34 & 42,77 & 47,44 & 48,37 & 49,58 & 51,99 & 47,57 & 48,08 & 41,09 & 40,97 & 55,66 & 64,79 & 62,96 & 63,49 & 62,44 \\
\hline Média Capital & - & - & - & - & - & - & - & - & - & - & 17,31 & 20,36 & 15,67 & 15,53 & - & - & - & - & - \\
\hline Sonae & 15,68 & 13,65 & 12,91 & 11,14 & 11,77 & 11,27 & 10,60 & 11,26 & 10,69 & 9,28 & 7,24 & 5,87 & 3,92 & 4,05 & 4,86 & 5,33 & 5,46 & 5,95 & 5,88 \\
\hline IGD & - & - & - & - & - & - & - & - & - & - & - & - & 7,80 & - & - & - & - & - & - \\
\hline Megafin & - & - & - & - & - & - & - & - & - & - & - & 1,19 & 2,04 & 2,47 & 3,40 & 3,52 & 3,38 & 3,03 & 5,87 \\
\hline Económico SGPS & 1,49 & 1,94 & 2,31 & 2,70 & 2,51 & 2,61 & 2,53 & 2,11 & 2,34 & 2,21 & 1,94 & 1,73 & 1,20 & 1,36 & 1,93 & 2,44 & 2,51 & 2,70 & 2,55 \\
\hline I Informação & - & - & - & - & - & - & - & - & - & - & - & - & - & - & 1,14 & 1,60 & 1,44 & 1,15 & 1,05 \\
\hline Total & 100 & 100 & 100 & 100 & 100 & 100 & 100 & 100 & 100 & 100 & 100 & 100 & 100 & 100 & 100 & 100 & 100 & 100 & 100 \\
\hline
\end{tabular}

Note. Source: APCT. 